\title{
Behavioral context of call production by eastern North Pacific blue whales
}

\author{
Erin M. Oleson ${ }^{1, *}$, John Calambokidis ${ }^{2}$, William C. Burgess ${ }^{3}$, Mark A. McDonald ${ }^{4}$, \\ Carrie A. LeDuc ${ }^{5}$, John A. Hildebrand ${ }^{1}$
}

${ }^{1}$ University of California San Diego, Scripps Institution of Oceanography, 9500 Gilman Drive No. 0205, La Jolla, California 92093, USA

${ }^{2}$ Cascadia Research Collective, 218 $\frac{1}{2}$ W 4th Avenue, Olympia, Washington 98501, USA

${ }^{3}$ Greeneridge Sciences, 4512 Via Huerto, Santa Barbara, California 93110, USA

${ }^{4}$ Whale Acoustics, 11430 Rist Canyon Road, Bellvue, Colorado 80512, USA

${ }^{5}$ NOAA Fisheries, Southwest Fisheries Science Center, 8604 La Jolla Shores Drive, La Jolla, California 92037, USA

\begin{abstract}
We assessed the behavioral context of calls produced by blue whales Balaenoptera musculus off the California coast based on acoustic, behavioral, and dive data obtained through acoustic recording tags, sex determination from tissue sampling, and coordinated visual and acoustic observations. Approximately one-third of 38 monitored blue whales vocalized, with sounds categorized into 3 types: (1) low-frequency pulsed A and tonal B calls, in either rhythmic repetitive song sequences or as intermittent, singular calls; (2) downswept D calls; and (3) highly variable amplitudeor frequency-modulated calls. Clear patterns of behavior, sex, and group size are evident for some call types. Only males were documented producing $\mathrm{AB}$ calls, with song produced by lone, traveling blue whales, and singular AB calls were more typically produced by whales in pairs; D calls were heard from both sexes during foraging, commonly from individuals within groups. The sex bias evident in $\mathrm{AB}$ callers suggests that these calls probably play a role in reproduction, even though the calls are produced year-round. All calls are produced at shallow depth, and calling whales spend more time at shallow depths than non-calling whales, suggesting that a cost may be incurred during D calling, as less time is spent feeding at deeper depths. This relationship between calling and depth may predict the traveling behavior of singing blue whales, as traveling whales do not typically dive to deep depths and therefore would experience little extra energetic cost related to the production of long repetitive song bouts while moving between foraging areas.
\end{abstract}

KEY WORDS: Blue whale $\cdot$ Acoustics $\cdot$ Suction-cup tag $\cdot$ Sex bias $\cdot$ Calls $\cdot$ Foraging

Resale or republication not permitted without written consent of the publisher

\section{INTRODUCTION}

Mysticete whales produce a wide variety of sounds (Evans 1967, Edds-Walton 1997), but relatively few researchers have attempted to link sound production with specific behaviors or environmental conditions to derive the functional significance of calls. The first theories regarding the use of sound by mysticetes suggested that the patterned sounds were used for echosensing (Patterson \& Hamilton 1964). Since that time, other uses of sound, similar to the use of sound by other mammalian species, have been suggested, including mate attraction (Evans 1967) and long-range communication with conspecifics (Payne \& Webb 1971).

The behavioral context of sound production has been determined for a subset of calls produced by some well-studied species, including the humpback whale Megaptera novaeangliae, the southern right whale Eubalena australis, and the North Atlantic right whale E. glacialis. Humpback whales produce differ- 
ent sound types in association with different behavioral and environmental contexts, including singing primarily on low-latitude breeding grounds (Payne \& McVay 1971) and coordinated feeding calls in Alaskan waters ( $D^{\prime}$ Vincent et al. 1985). Call production in the southern right whale varies with activity level (Clark 1983). North Atlantic right whales produce a variety of sounds in surface-active groups, with specific sounds produced by the focal female and other distinct sound types produced by the males and calves (Parks \& Tyack 2005). In humpback (Winn \& Winn 1978, Darling 1983) and fin Balaenoptera physalus (Croll et al. 2002) whales, songs are produced only by males, suggesting that they serve a reproductive purpose. Detailed behavioral observations during calling in other species are rare, in particular in the blue whale $B$. musculus.

Evaluation of the behavioral context of calling has been plagued by the difficulty of associating calling, which occurs underwater and out of view, with visual observations that occur at the surface prior to or after the call has been produced. When groups of whales are present, it is often difficult to determine which individual is vocalizing and to track it from one visual encounter to the next. Miniature self-contained acoustic recording tags, capable of recording dive depth and body orientation, allow evaluation of whale behavior during call production. Combined with surface behavioral observations and skin sampling, diving and acoustic behavior recorded on the tag may be used to infer behavioral and environmental contexts of call production. Assessment of calling behavior may include detailed measures of calling depth, overall dive behavior, surface behavior, sex, and association with conspecifics. The detailed behavior of calling whales may also be compared to that of non-calling whales to examine differences in behavior, providing insight into the motivation for calling and the costs associated with it. In addition, observations of calling and behavior using acoustic recording tags provide the information necessary to begin to develop models of whale distribution, abundance, and habitat use from longterm acoustic data collected by other systems.

Four unique sounds have been previously described from the eastern North Pacific population of blue whales (Thompson 1965, Thompson et al. 1996, Thode et al. 2000, McDonald et al. 2001). The best-described vocalizations consist of a combination of 2 lowfrequency, long-duration sounds: pulsed
A calls and tonal B calls (Fig. 1a). Repetitive A and B call sequences have been classified as song (McDonald et al. 2006), similar to song production in humpback and fin whales. Blue whale song has been documented along the entire migratory route from feeding areas extending from California to the Gulf of Alaska (Stafford et al. 2001, Stafford 2003, Burtenshaw et al. 2004) to the winter breeding grounds near Mexico (Thompson et al. 1996) and the Costa Rica Dome, where song is heard year-round (Stafford et al. 2001). Blue whales also produce downswept sounds, known as D calls (Fig. 1b) (Thompson et al. 1996, McDonald et al. 2001). These calls have a greater variation in frequency and duration than A and B calls and have been heard from blue whales in several regions, including the Antarctic (Rankin et al. 2005), North Atlantic (Mellinger \& Clark 2003), and within much of the eastern North Pacific blue whale range (Thompson et al. 1996, McDonald et al. 2001). The behavior of individual blue whales producing $\mathrm{D}$ calls has not been reported. Several unusual, highly variable frequencymodulated (FM) sounds, some similar in frequency to B and $\mathrm{D}$ calls, also have been recorded (Thode et al. 2000).

In this study we evaluated the behavioral context of call production by blue whales along the California coast with the goal of understanding how call production varies with sex and behavior. Non-acoustic behaviors associated with calling vary by call type, indicating a unique behavioral context for song versus other calls.

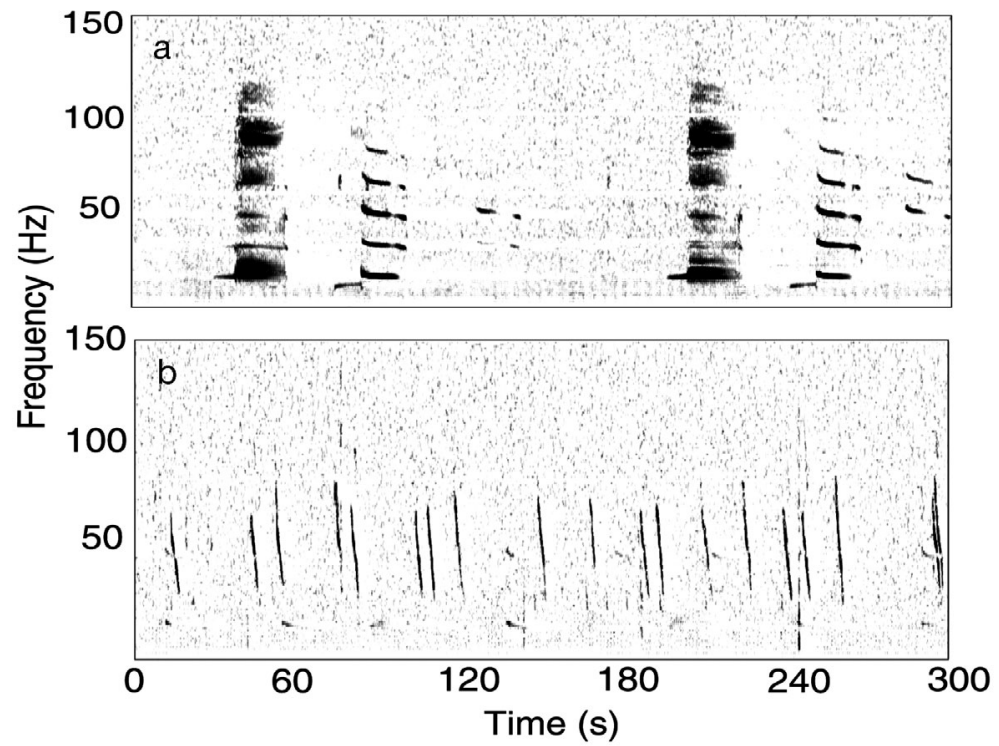

Fig. 1. Balaenoptera musculus. Calls of northeast Pacific blue whales. (a) Pulsed A and tonal B call pairs occurring in a repeated song sequence; B calls from a different blue whale are also evident; spectrogram parameters: fast Fourier transform (FFT) length $=1 \mathrm{~s}, 90 \%$ overlap, Hanning window. (b) Variable downswept D calls, with faint AB song; spectogram parameters: FFT length $=1 \mathrm{~s}, 25 \%$ overlap, Hanning window 
Our observations provide information about the behavioral context for call types that have been widely heard and documented but not understood in terms of their biological and ecological context.

\section{MATERIALS AND METHODS}

Blue whale calling behavior was observed using acoustic recording tags or from simultaneous visual and acoustic tracking. This study was not designed to collect a specific number of samples from calling or non-calling whales, but instead to provide observations of calling behavior upon which to develop hypotheses for future studies. Tagging and tracking of blue whales was conducted during 6 summer and fall feeding seasons in several locations along the California coast, including the Southern California Bight, Monterey Bay, and near Point Reyes (Fig. 2).

In this paper we use 'call' to describe all vocalizations. The consistent organization of calls into stereotypic, repeated phrases is termed 'song' (McDonald et al. 2006). For blue whales, song consists of an A call followed at a fixed time interval by 1 or more B calls, with this sequence repeated at a regular interval.

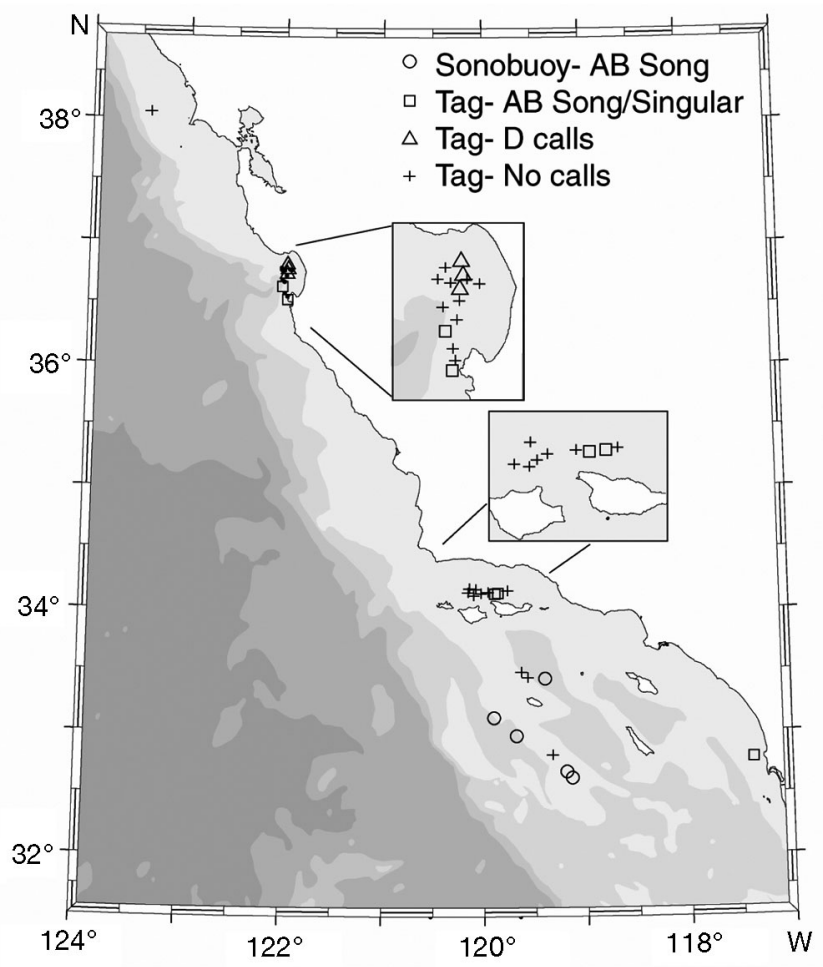

Fig. 2. Balaenoptera musculus. Location map for all tagged and tracked blue whales observed in this study. Key shows types of calls heard during the various tag deployments. Monterey Bay and Santa Barbara Channel regions are shown in detail as insets
Although blue whale songs are simple in structure, stereotypic repetitive phrasing is consistent in definition with that used for songs of birds (Kroodsma \& Miller 1982), insects, terrestrial mammals, and other baleen whales (Payne \& McVay 1971).

Tagging. Three types of acoustic recording tags were deployed: the National Geographic Crittercam (Marshall 1998), the Woods Hole Oceanographic Institution (WHOI) D-tag (Johnson \& Tyack 2003), and the Bioacoustic Probe (B-probe; Greeneridge Sciences). Crittercam is an integrated video-camcorder and datalogging system that records depth, temperature, and uncalibrated sound up to $24 \mathrm{kHz}$, in addition to video (Marshall 1998). Video and audio data are stored to Hi8 videotape and depth is stored to RAM. Crittercams were deployed earliest in the study, when the focus was primarily on feeding behavior. While Crittercams provided depth and visual information, the recording duration was limited to a few hours and the acoustic data was often discarded due to electrical interference. Only those records including acoustic data free of electronic interference were included in this analysis. In 2002, deployments transitioned to increased use of digital acoustic tags, which provide high-quality acoustic data and longer recording duration. Initial deployments of digital tags used the D-tag. The technical specifications and deployment systems of the D-tag are described in detail elsewhere (Johnson \& Tyack 2003). The D-tag acoustic data from these deployments was internally high-pass filtered at $400 \mathrm{~Hz}$ to reduce the contribution of flow noise energy in the acoustic record and was not calibrated at frequencies below $100 \mathrm{~Hz}$. Only acoustic and dive depth data were analyzed from D-tag records. The D-tag is not commercially available and was used during only one period as part of a collaborative effort with WHOI.

The B-probe, of primary use in this study, is a commercially available electronic data-logging tag that records pressure, temperature, and sound up to a maximum sample rate of $20 \mathrm{kHz}$. The B-probe provides calibrated acoustic pressure data with a flat frequency response between 10 and $7400 \mathrm{~Hz}$, with 16-bit resolution and a sensitivity of $-190 \mathrm{~dB}$ re: $1 \mu \mathrm{Pa}$. With flotation and suction cups, the B-probe is approximately $33 \mathrm{~cm}$ long and $6 \mathrm{~cm}$ in diameter. The 2003 and later versions of the B-probe include a 2-axis accelerometer, enabling the derivation of instantaneous body orientation (i.e. tilt and roll), as described by Goldbogen et al. (2006). An offset in the roll values, evident when the whale is upright during surface intervals, and due to the location of the tag on the body, was subtracted following each surface interval. Body orientation is defined relative to horizontal $\left(0^{\circ}\right.$ tilt $)$ and dorsal side up $\left(0^{\circ}\right.$ roll $)$, where positive tilt angles indicate a head-up position, and positive roll angles correspond to canting 
to the right and negative to the left. All tags were set to an acoustic sample rate of $1024 \mathrm{~Hz}$, with auxiliary channels (e.g. pressure, temperature, accelerometers) sampling at $1 \mathrm{~Hz}$.

Deployment of acoustic recording tags was conducted opportunistically from ship-based surveys in the Southern California Bight and during shore-based tagging operations in southern and central California. All acoustic recording tags were attached without a priori knowledge of the whale's vocal behavior. Blue whales were selected for tagging based on our ability to locate and track them visually. When chosen for tagging, a whale was approached from behind using a $5.3 \mathrm{~m}$ RHIB (rigid-hulled inflatable boat) to within $\sim 1$ to $5 \mathrm{~m}$. A tag was attached to the whale using a $2.6 \mathrm{~m}$ metal or $5 \mathrm{~m}$ fiberglass pole with a specially designed bracket to hold the tag in place yet allow it to detach from the pole after becoming attached to the whale. The tag was held on the whale with suction cups. Skin was collected from tagged individuals, either from the inner surface of the suction cup or tagging apparatus or by biopsy. Tagged whales were followed by either the RHIB or the survey vessel to monitor surfacing location, surface behavior, and the location of other blue whales in the vicinity. The distance between the tagged whale and others nearby was estimated by an experienced observer when each whale was at the surface.

Upon tag retrieval, digital data were downloaded from the tag to a computer for analysis. Tag records were only included in this analysis if the tag remained on the whale for at least $15 \mathrm{~min}$. Acoustic data were viewed in spectrogram form (fast Fourier transform [FFT] length $1 \mathrm{~s}, 80 \%$ overlap, Hanning window) to determine the presence of calls; the time was noted for comparison to the pressure and accelerometer records, when available, and the call was extracted and saved as a sound file for further analysis. Diving behavior was qualitatively assessed and assigned to 1 of 4 categories, comprising feeding (evidenced by vertical lunges), shallow diving (most dives $<50 \mathrm{~m}$ ), deep diving (most dives $>50 \mathrm{~m}$ ), or variable (dives to various depths, no vertical lunges) (see Table 1 ).

Calling was ascribed to the tagged whale based on the following process. Received levels and signal-tonoise ratio (SNR) were calculated for each call. If no other blue whales were present within $1 \mathrm{~km}$ and calls were detected at consistently high SNRs and received level, we attributed the call to the tagged whale. Calls from distant whales would have low SNR due to flow noise generated from the swimming tagged whale. If the calling whale was paired, we evaluated the surface behavior of both whales during the call and the flow noise measured on the tag. Because the sea surface is a reflective boundary, calls occurring close to it (i.e. within $1 / 8$ of an acoustic wavelength, or approximately $12 \mathrm{~m}$ for B calls and $5 \mathrm{~m}$ for D calls) would be largely attenuated by the destructive interference of the reflecting sound (Urick 1983), greatly reducing the received level of calls produced at or near the surface. We therefore ascribed loud calling to the tagged whale if its paired whale was at the surface when the call was detected. When both whales were underwater, and therefore assignment of calls to the tagged whale remained ambiguous, we measured the flow noise on the tag. Below $50 \mathrm{~Hz}$, the flow noise in the tag acoustic record increases approximately quadratically from 0 to $5 \mathrm{~m} \mathrm{~s}^{-1}$ swimming speed (Goldbogen et al. 2006), such that at $0 \mathrm{~m} \mathrm{~s}^{-1}$ the background noise was $112 \mathrm{~dB}$ re: $1 \mu \mathrm{Pa}$ and increased to $171 \mathrm{~dB}$ re: $1 \mu \mathrm{Pa}$ at $5 \mathrm{~m} \mathrm{~s}^{-1}$. The amplitude of the flow noise measured on the tag and the distance from the tagged whale to others nearby were evaluated to determine if calls from the nearby whales could be heard above the noise. For example, a whale producing calls near the maximum reported source level of $190 \mathrm{~dB}$ re: $\mu \mathrm{Pa} 1 \mathrm{~m}$ (McDonald et al. 2001 ) at $50 \mathrm{~m}$ distance from the tag would be audible above the background noise if the tagged whale was moving at less than $2.5 \mathrm{~m} \mathrm{~s}^{-1}$. Given this relationship between flow noise and swimming speed, we assigned calls to a tagged whale moving at $1 \mathrm{~m} \mathrm{~s}^{-1}$ or less if no other whales were present within $200 \mathrm{~m}$. If the tagged whale was moving at $3 \mathrm{~m} \mathrm{~s}^{-1}$ or faster, nearby whales could not be heard if more than 1 body length from the tagged whale. When flow noise did not provide an unambiguous result as to the identity of the calling whale, we did not attempt to assign the calls to either whale, as this could have indicated production of calls by either or both whales.

Acoustic and visual tracking. Behavioral information and biopsies of singing blue whales were opportunistically collected during periodic ship-based surveys in the Southern California Bight on the RV 'Robert Gordon Sproul' between 2000 and 2003. Singing blue whales were tracked using directional fixing and ranging (DIFAR) sonobuoys. Acoustic signals were monitored in real-time as spectrograms using the software 'Ishmael' (Mellinger 2002). When songs were detected in the spectrogram display, the bearing to the sound source was estimated using the relative signal strength in the east-west and north-south components of the sonobuoy signal (McDonald 2004). Often, 2 or more sonobuoys would detect the same song, allowing the acoustics team to estimate the position of the singing whale using the intersection of bearing angles. These positions aided the visual observer team in locating the singing whale. Visual observers searched from the bridge wings of the 'Sproul' ( $7 \mathrm{~m}$ above the water) for the singing blue whale using $7 \times 50$ power binoculars and the naked eye. Singing whales were identified 
based on their location relative to sonobuoy bearings, the relative amplitude and timing of song components from other singing whales, and the coincidence of gaps in the song with observation of the focal whale at the sea surface.

When a calling whale was located, the RHIB was launched from the 'Sproul' to approach the calling whale to obtain a skin biopsy and photographs for individual identification (photo-ID). Procedures have been described in more detail elsewhere (McDonald et al. 2001). Following collection of a skin sample from the focal whale, a sonobuoy was deployed by the RHIB at the location of the surfacing whale. Correct identification of the singing whale was verified based on (1) loud calls from the direction of the biopsied whale, and (2) saturation of the sonobuoy signal due to the high received levels of a whale call produced in very close proximity to the receiver. Each sampled singer was then visually followed in the RHIB in order to record surface locations and observe surface behavior, direction of movement, and the proximity of non-vocal conspecifics. The locations of other vocalizing whales were tracked with sonobuoys.

Statistical analyses. All statistical tests were carried out using the software package S-Plus 6.0. Univariate comparisons between call character group means were significance tested using the Student's $t$-test assuming unequal variances $(\alpha=0.05)$. Differences in diving behavior between calling and non-calling whales were evaluated by calculating, for each whale, the percentage of time spent at shallow $(<50 \mathrm{~m})$ versus deep $(>50 \mathrm{~m})$ depth, not including surface intervals. The shallow versus deep frequencies were averaged across the sample according to behavior (traveling, feeding, and calling) and group mean frequencies for calling versus non-calling whales were compared using a chi-squared analysis.

Sex bias in call production was tested using a permutation test based on the genetic results of samples collected from tagged and tracked whales. The results for all sex-typed whales (Morin et al. 2005) were pooled and a number of samples were chosen at random corresponding to the number of sex-typed whales producing a particular call type. The sex ratio was calculated for the randomly chosen samples, and the process was repeated 5000 times. The total number of outcomes corresponding to the observed sex ratio was divided by the number of permutations to calculate the probability of sampling the observed ratio by chance.

\section{RESULTS}

We monitored the calling behavior of 38 individual blue whales (Table 1) through visual and acoustic tracking of a focal singing whale $(n=5)$ and through the deployment of acoustic recording tags ( $\mathrm{n}=33$ ). Four call modes were observed from 13 calling whales, including production of $A B$ song $(n=6)$, intermittent production of $\mathrm{A}$ and $\mathrm{B}$ calls (i.e. non-song sequences; $\mathrm{n}=5)$, downswept $\mathrm{D}$ calls $(\mathrm{n}=3)$, and highly variable amplitude-modulated (AM) and FM calls $(n=1)$. One whale was heard intially producing singular A and $B$ calls before transitioning into song, and 1 record contained both D and highly variable AM and FM calls. When present, calls were always detected within 30 min of tag attachment.

Skin samples were obtained from 27 of 38 tagged or tracked blue whales and 6 whales closely associated with the focal whale. Sex was determined for 6 whales heard producing A and B calls, 3 producing D calls, and 17 non-vocal blue whales, including 4 associated whales (Table 1). Sex was also determined for 2 whales thought to be producing $\mathrm{AB}$ calls; however, assignment of calls to the tagged whale could not be verified.

\section{New call types}

Five deployments of acoustic recording tags on blue whales included the occurrence of A and B calls not occurring in song sequences. The number and signal characteristics of these calls are presented in Table 2. These intermittent calls will be referred to as singular A and/or B calls and include Type A calls not followed immediately by a B call, B calls without a preceding A, or a single $A B$ call pair. Mean call duration of song and singular A and song and singular B calls was not significantly different $(A: p=0.744 ; B: p=0.088)$, nor was the mean time interval between song and singular A and $B$ units when they occurred in an AB call pair $(p=0.488)$. Some significant differences were found between song and singular A and song and singular B start and end frequencies $\left(\mathrm{A}_{\text {start }}: \mathrm{p}=0.168 ; \mathrm{A}_{\text {end }}: \mathrm{p}=0.030 ; \mathrm{B}_{\text {start }}: \mathrm{p}=\right.$ $\left.0.034 ; B_{\text {end }}: p=0.121\right)$. It is not clear if the differences between start and end frequencies represent a characteristic difference between the song and singular call types or are an artefact of confounding factors (discussed later). Singular AB calls were primarily distinguished from song by low call rates $(p<0.001)$ and inconsistent intervals between successive calls other than the interval between A and B units in an AB call pair $(\mathrm{p}<0.001)$.

Variable AM and FM calls, produced with D calls (Fig. 3), have distinct frequency, duration, and modulation (Table 2) relative to previously observed call types (Fig. 1). Some of the calls appear to be similar to Type $\mathrm{B}$ calls because of their frequency content; however, these calls exhibited greater frequency modulation and were consistently shorter in duration than song or singular B calls (Table 2). 


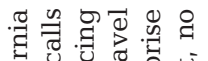

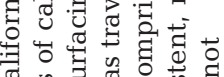

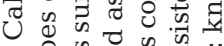

ত

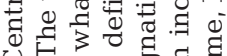

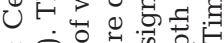

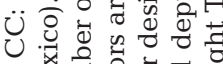

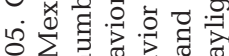

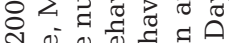

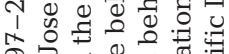

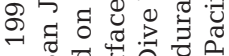

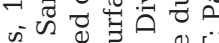

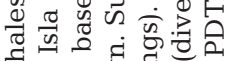

उ ซ ซ

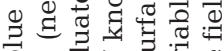

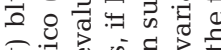

Sir.

$\because \sum \sum_{0}$

실

$\sum \omega_{0}$ 券

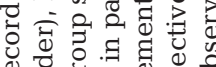

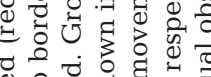

ब. ठ छ

S

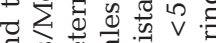

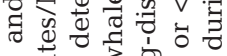

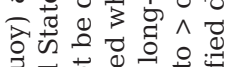

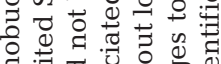

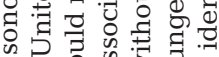

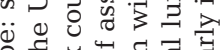

政

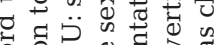

$0.0 \%$

ब्र

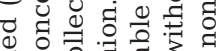

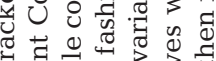

$\Xi$.

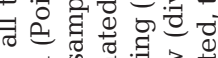

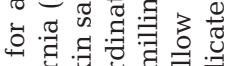

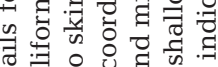

चี

ช

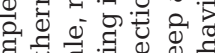

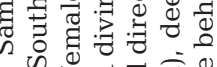

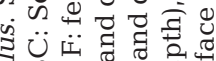

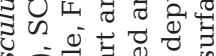

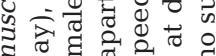

व

बें

政

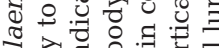

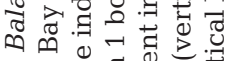

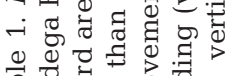

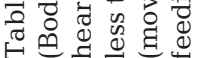

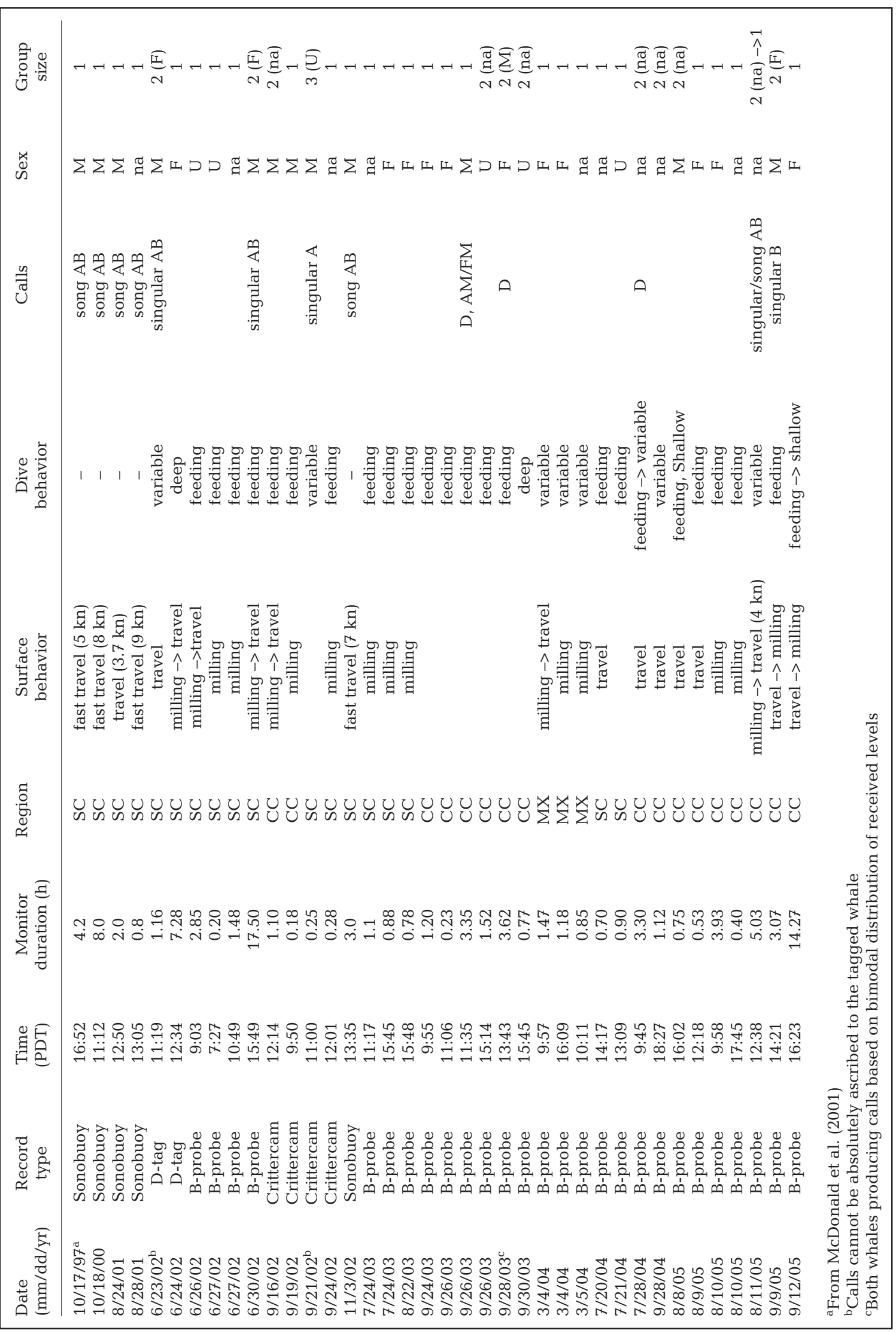


Table 2. Balaenoptera musculus. Call characteristics of blue whales tracked in this study. Mean $( \pm \mathrm{SD})$ of each signal characteristic was calculated for each whale and then combined to form a single estimate for that characteristic. Call frequencies were measured from spectrogram displays (FFT length $=1 \mathrm{~s}, 50 \%$ overlap, Hanning window) and inter-call interval was measured from the onset of one call to the onset of the next

\begin{tabular}{|c|c|c|c|c|c|c|c|c|}
\hline \multirow[t]{2}{*}{ Call type } & \multirow{2}{*}{$\begin{array}{c}\mathrm{n} \\
\text { whales }\end{array}$} & \multirow{2}{*}{$\begin{array}{c}\mathrm{n} \\
\text { calls }\end{array}$} & \multicolumn{2}{|c|}{ Frequency } & \multirow{2}{*}{$\begin{array}{c}\text { Call } \\
\text { duration (s) }\end{array}$} & \multicolumn{2}{|c|}{ Intercall interval (s) } & \multirow{2}{*}{ 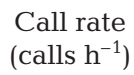 } \\
\hline & & & start (Hz) & end (Hz) & & A-B & B-A & \\
\hline \multicolumn{9}{|l|}{ Song } \\
\hline A & 5 & 63 & $89.9 \pm 2.3$ & $86.3 \pm 1.9$ & $15.2 \pm 1.7$ & $47.8 \pm 3.7$ & $83.0 \pm 25.1$ & $43.3 \pm 4.5$ \\
\hline B & 6 & 90 & $52.2 \pm 0.7$ & $46.6 \pm 1.1$ & $16.6 \pm 1.2$ & & & \\
\hline \multicolumn{9}{|l|}{ Singular } \\
\hline A & 3 & 42 & $87.7 \pm 1.4$ & $84.9 \pm 1.6$ & $14.1 \pm 3.4$ & $47.1 \pm 1.7$ & $983.5 \pm 743.5$ & $3.9 \pm 3.3$ \\
\hline B & 4 & 20 & $50.1 \pm 0.8$ & $45.6 \pm 0.8$ & $14.4 \pm 3.5$ & & & \\
\hline \multicolumn{9}{|l|}{ D/AM/FM } \\
\hline $\mathrm{D}$ & 3 & 56 & $75.7 \pm 15.6$ & $39.3 \pm 9.9$ & $1.8 \pm 1.01$ & (D-D) $835.3 \pm 1097.0$ & $4.0 \pm 3.7$ & \\
\hline $\mathrm{AM} / \mathrm{FM}$ & 1 & 10 & $45.4 \pm 7.6$ & $45.0 \pm 9.1$ & $2.2 \pm 0.8$ & & & \\
\hline
\end{tabular}
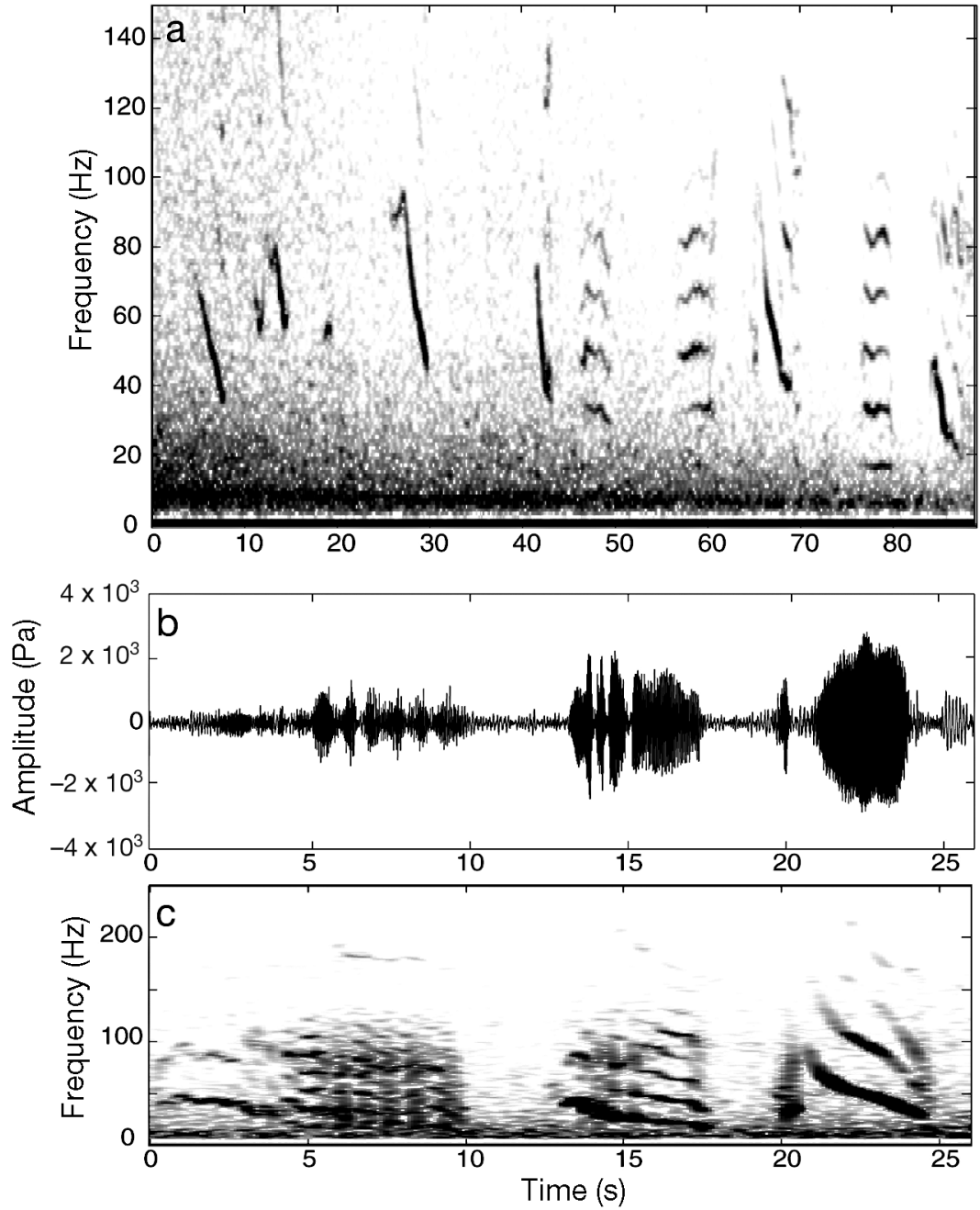

Fig. 3. Balaenoptera musculus. (a) Spectrogram of D calls and highly variable tonal calls recorded by tag on September 26, 2003, in Monterey Bay; D calls are quite variable, with different starting and ending frequencies for each call; the tonal calls are frequency-modulated (FM) and similar in frequency content to normal B calls but are of shorter duration: FFT length $=1 \mathrm{~s}, 50 \%$ overlap, Hanning window. (b) Time series. (c) Spectrogram of 3 sequential AM (amplitudemodulated) and FM calls from the same tag deployment; FFT length $=1 \mathrm{~s}$, $90 \%$ overlap, Hanning window

\section{Sex bias in call production}

All samples collected from whales either producing $(n=6)$ or suspected to be producing $(\mathrm{n}=2) \mathrm{A}$ and B calls were male. Three skin samples collected from D callers indicate that both sexes produce this call type ( 2 males, 1 female). Calls were not detected from 14 females and 3 males. The observed sex ratio of the $A B$ callers based on 5000 random permutations was significantly different from that expected by chance (0.005), providing strong evidence that only males produce A and B calls.

\section{Calling behavior}

Evaluation of surface and diving behaviors and group size (Table 1) reveal a relationship between behavior and call production. Behavior was evaluated for AB song, singular A and/or B calls, and D calls. The behavior of 1 whale producing highly variable AM and FM calls was pooled with other D callers.

All singing whales were observed in only 1 of the defined behavioral states: traveling. Surface observations of all singing blue whales consisted of steady movement in a consistent direction for the duration of the monitoring period. Lunge-feeding dives were not observed on the tag record immediately before, during, or after song production. In addition, singing whales were not paired with other blue whales during the period of singing, although other blue whales 
were occasionally within a few kilometers of the singer.

The behaviors associated with singular A and/or B calls were different from those associated with song. Singular AB calling whales were always in close association (i.e. paired or grouped) with at least 1 additional blue whale, and other blue whales were generally present within $1 \mathrm{~km}$. A variety of surface and diving behaviors were observed from singularly calling whales, including feeding, milling, resting, and traveling (Fig. 4, Table 1). When tissue samples of associate whales were available, female whales were paired with the caller. The distance between the caller and its pair varied from a few meters (as seen on the Crittercam) to several tens of meters, such as when the other whale in the pair was at the surface while the call was produced at depth.

A transition from singular to song calling was observed on 1 tag record (Fig. 5). The acoustic, dive, and surface behavior of this whale showed it singular calling while paired with another blue whale, followed by singing after traveling away from its pair, consistent with the traveling behavior observed for other singing whales.

D calls were produced during shallow dives (i.e. $<35 \mathrm{~m}$ ) by whales that were otherwise engaged in lunge-feeding at greater depths (i.e. $>80 \mathrm{~m}$ ). Two of 3 tag attachments recording D calls were on whales in loosely associated pairs, such that the other whale did not always surface with the tagged whale, but sometimes at a different time at a nearby location. The third record was from a single whale. Additional blue whales were always within $1 \mathrm{~km}$ of the tagged whale, though there was no observable coordinated behavior between the tagged whale and these more distant animals. One example of the diving and surface behaviors of a paired D-calling whale is shown in Fig. 6. Calls were heard prior to the pair separating and when they joined together, as well as at other times. We observed great variation in the received level of sequential calls in this recording, probably indicating that both whales in the pair were calling. This variation is illustrated for one dive in which a D call with high SNR was received, followed by 2 much

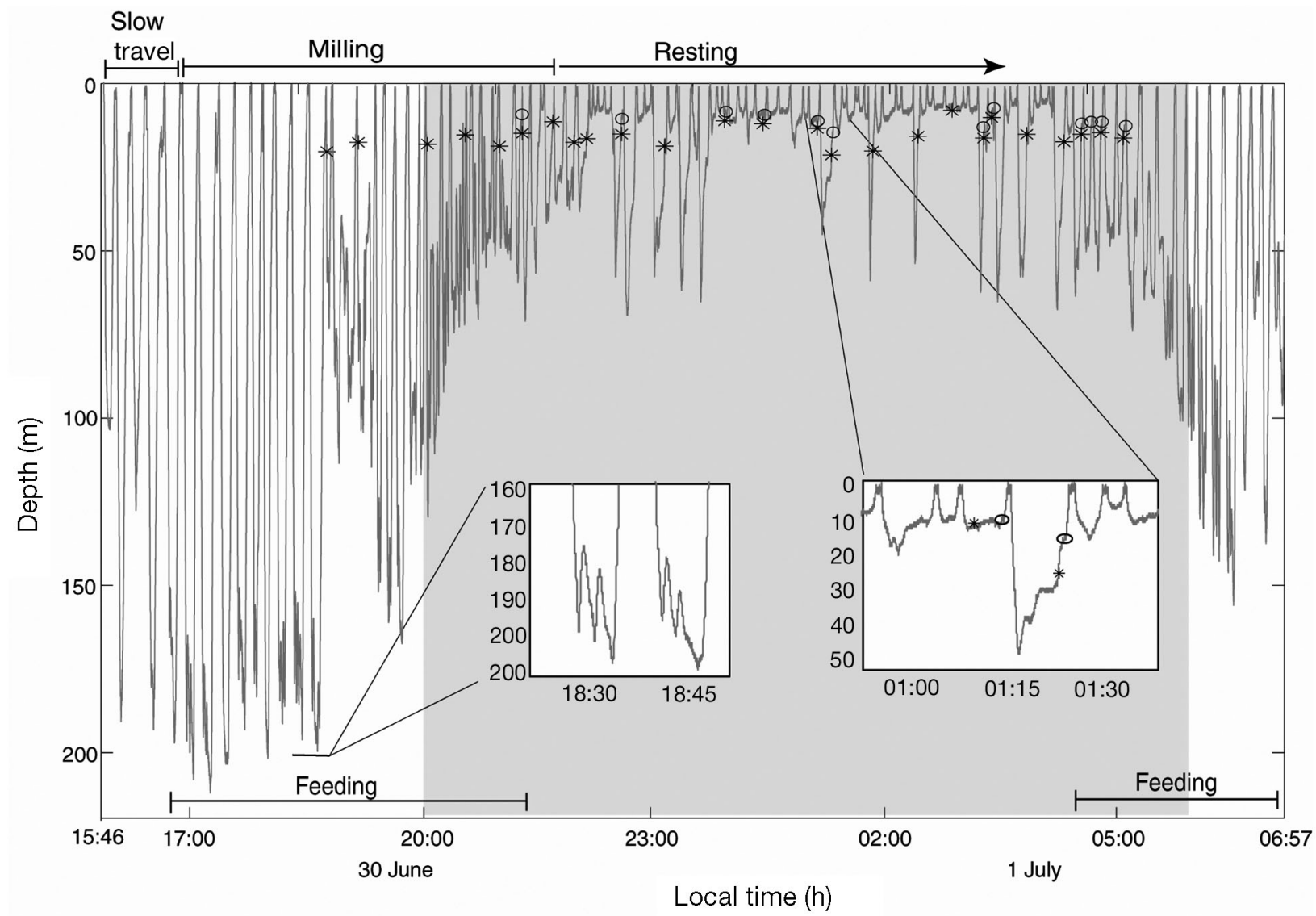

Fig. 4. Balaenoptera musculus. Dive profile of calling whale on June 30, 2002, tagged near La Jolla. Depth and time at which (*⿻) A and (O) B calls were received at the tag are indicated. The tagged whale's observed surface behavior is annotated along upper axis. Periods of lunge-feeding, evidenced by vertical lunges at depth, are denoted along lower axis. The period between sunset and sunrise is highlighted with grey shading. Insets show detail of lunge-feeding dives and dives including A and B calls 


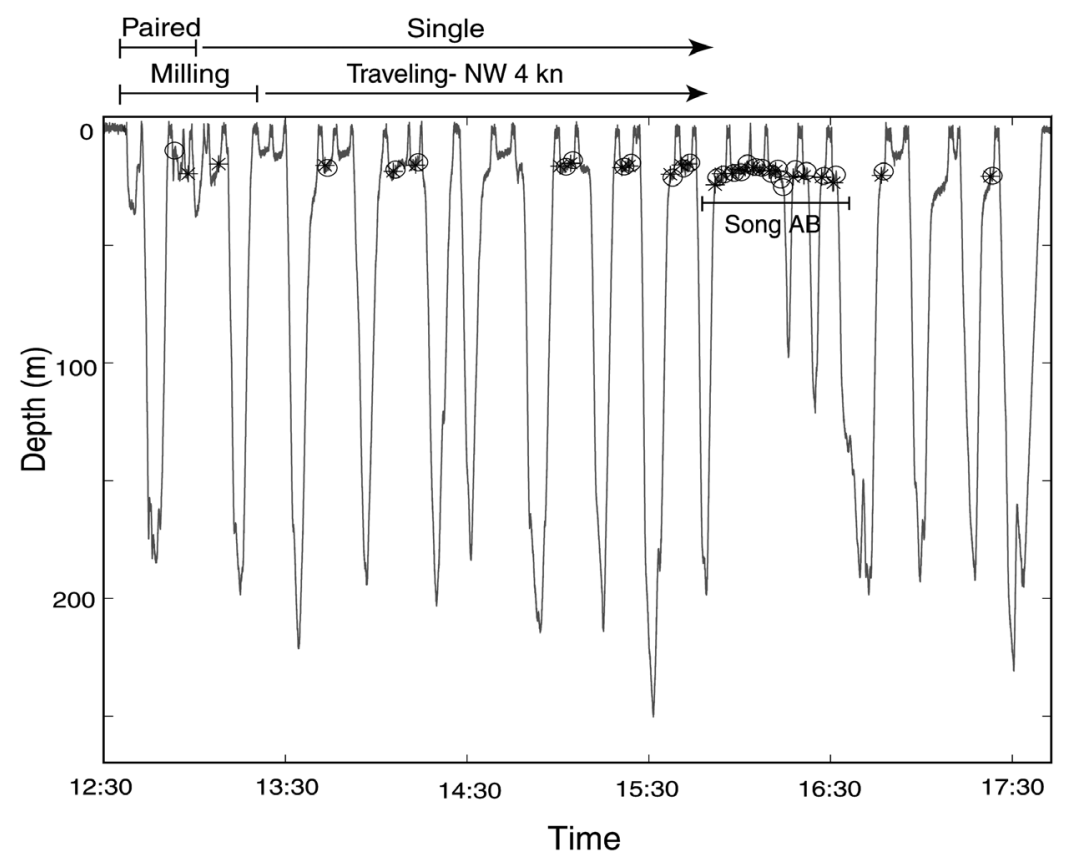

Fig. 5. Balaenoptera musculus. Dive profile of a blue whale transitioning from singular to song AB calling, observed on August 11, 2005, in Monterey Bay. Depth and time at which (*) A and (O) B calls were received at the tag are indicated. Tagged whale's surface behavior and group size are annotated along upper axis until surface observations ceased shortly after 15:30 h

lower amplitude calls, probably produced by the other whale in the pair (Fig. 6b).

\section{Call production}

The depth, tilt, and roll during call production reveal that calling is constrained to shallow depths and occurs near upright and horizontal orientation. All call types were produced at depths $<35 \mathrm{~m}$ with the average change in depth during the call of $<2 \mathrm{~m}$ (Fig. 7). In general, calls occurred during shallow dives, although deep dives prior to or following call production were occasionally observed for AB callers (Figs. 4 \& 5). Mean tilt angles varied between horizontal and $11^{\circ}$ headdown, while mean roll angles were within $3^{\circ}$ of dorsal side up. The number of calls produced per dive varied by call type, with 3 to 10 AB song units, a single A or B call or an $\mathrm{AB}$ pair, or up to $15 \mathrm{D}$ calls.

\section{Calling versus quiet behavior}

Calls were always heard at shallow depth $(<30 \mathrm{~m})$ while lunge-feeding in calling and quiet whales generally occurred at greater depth (>50 m). A significant difference in the proportion of time spent at shallow depth
( $<50 \mathrm{~m}$ ) was found between quiet feeding whales and whales producing $D$ and song or single AB calls (D: $p<0.001 ; A B: p<$ 0.001), indicating that calling whales spend more time at shallow depth than non-calling whales. Conversely, no difference was found between $\mathrm{D}$ or $\mathrm{AB}$ callers and non-calling traveling whales (D: $\mathrm{p}=$ 0.218; AB: $\mathrm{p}=0.771$ ).

To further compare the diving behaviors of calling versus quiet blue whales, we calculated the percentage of time each whale spent in $10 \mathrm{~m}$ depth bins beginning at $5 \mathrm{~m}$ depth. These profiles were then sorted according to behavior (traveling, feeding) and calling (Fig. 8). With the exception of increased time spent at shallow depth, the overall dive behaviors of calling whales were generally similar to those of non-callers. The profiles of the D callers and most singular AB callers showed increased time spent at deep depths corresponding to lunge-feeding there. Non-vocal traveling whales spent little time at depths deeper than $185 \mathrm{~m}$, similar to the behavior of singing and some singularly calling whales.

\section{DISCUSSION}

Understanding and interpreting blue whale calling behaviors requires finding patterns in the occurrence of different call types and their associated non-acoustic behaviors. Although the types of sounds produced by eastern North Pacific blue whales have been described by others (Thompson 1965, Thompson et al. 1996, Thode et al. 2000, McDonald et al. 2001), the social and behavioral contexts of calls was largely unknown. Our observations provide a preliminary understanding of blue whale calling behavior and suggest a unique context for two types of sounds, the AB song calls and D calls (Table 3). In addition, an apparent contextual variant similar to AB song calls has been newly documented.

\section{Song and singular AB calls}

Our observations of singing blue whales suggest a consistent context for this call type: solitary traveling males. Although long-distance communication may have occurred during calling, coordinated behavior was not observed between the singing whales des- 

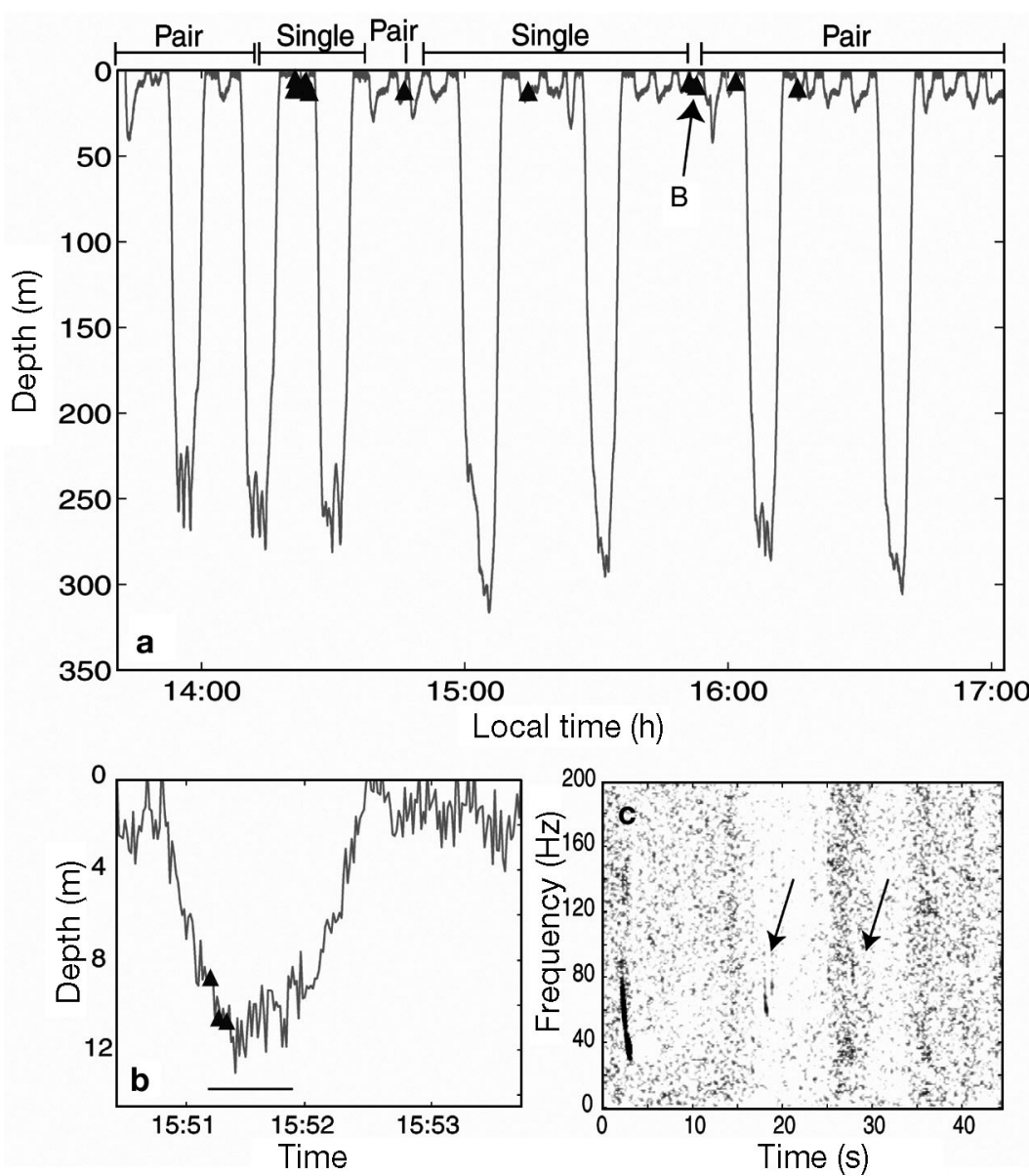

Fig. 6. Balaenoptera musculus. Dive profile for tagged whale of fluid pair observed September 28, 2003, in Monterey Bay. (a) Overall dive profile of tagged female; $(\boldsymbol{\Delta})$ times of medium- and high-SNR D calls; paired status of tagged female is annotated across top axis; B: 1 calling dive, shown in greater detail in (b), in which there may be counter-calls between whales in the joining pair. (b) High- and medium-SNR calls $(\mathbf{\Delta})$; horizontal bar indicates time period shown in (c). (c) Spectrogram showing counter-calls heard during calling dive in (b), with high-SNR call ascribed to the tagged female, and low-SNR calls (arrowed) ascribed to the untagged male in the pair cribed here and other whales in the area. Singing whales were not feeding, as evidenced both by the absence of lunge-dives associated with the capture of prey (Croll et al. 1998, AcevedoGutierrez et al. 2002) and by the traveling behavior exhibited (i.e. in contrast to the milling behavior that is associated with feeding at depth within a spatially confined prey patch). The high source levels (McDonald et al. 2001) and the repetition and duration of the individual blue whale A and B song units (Table 2), suggest that this call type is designed for communication over long distances (Payne \& Webb 1971, Clark \& Ellison 2004). The production of song exclusively by males suggests it is probably also reproductive in function (Bradbury \& Vehrencamp 1998).

Song is produced exclusively by males in other baleen whale species (Darling 1983, Croll et al. 2002), supporting our conclusion that songs may play a role in reproduction. The most extensively studied of these species is the humpback whale. In contrast to the relatively simple 2-part song of eastern North Pacific blue whales, humpback whales produce long complex songs consisting of rhythmically repeated phrases (Payne \& McVay 1971). The precise function of humpback song is still unknown (Payne \& McVay 1971, Tyack 1981, Clapham 1996); however, it may function to mediate interactions between males (Tyack 1981, Darling 1983, Darling \& Berube 2001) or to advertise species,
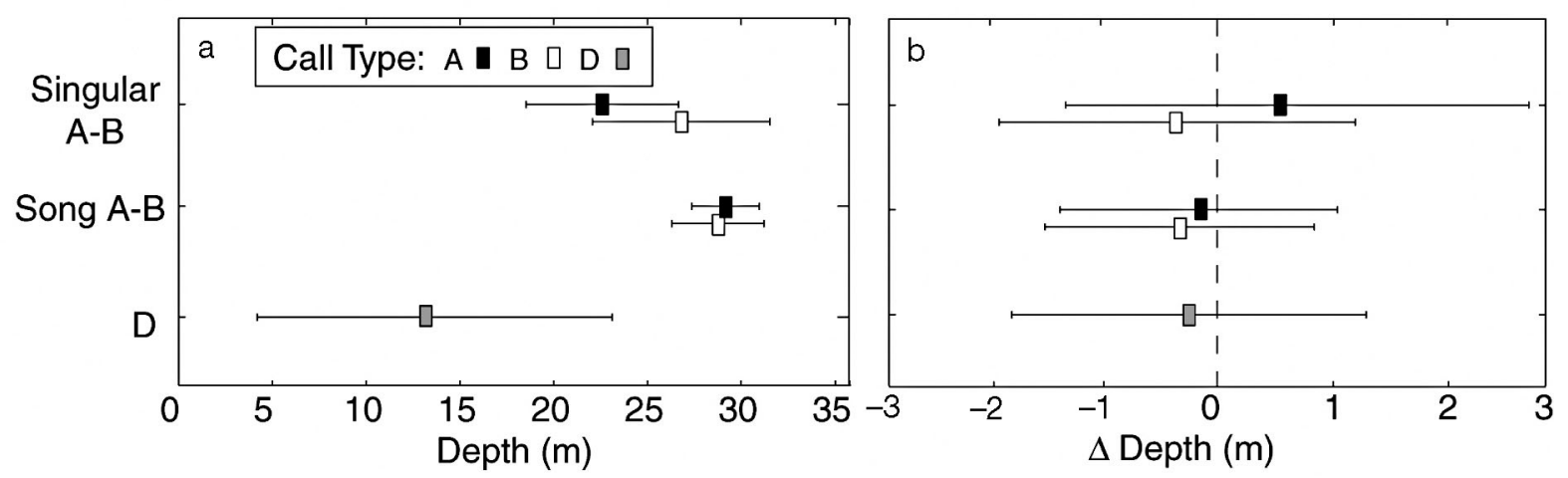

Fig. 7. Balaenoptera musculus. (a) Average depth and (b) change in depth during call production among whales producing song $A B$, singular $A B$, and $D$ type calls. Data are means $\pm S D$; vertical dashed line in (b) indicates zero change in depth 

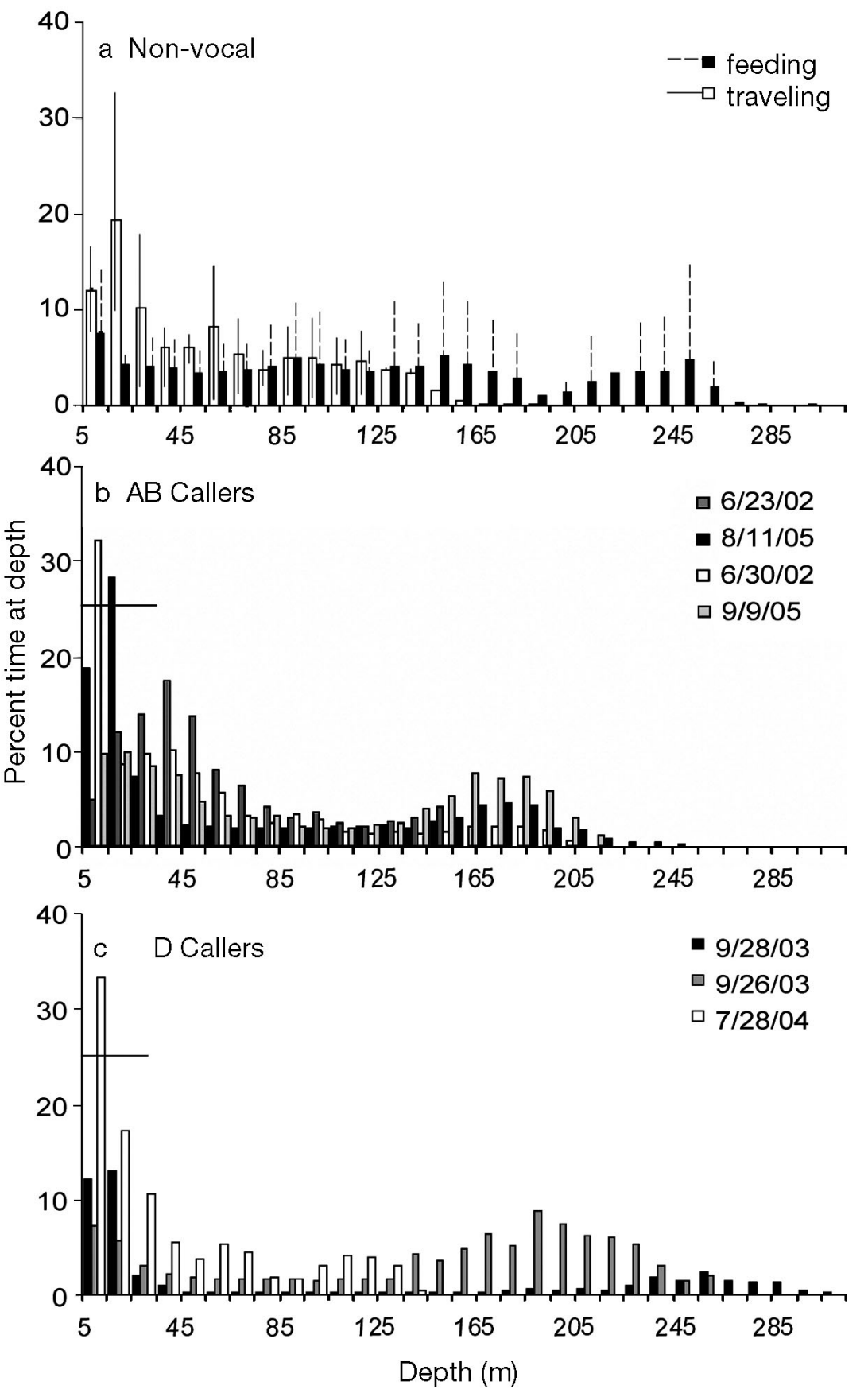

Fig. 8. Balaenoptera musculus. Percent time at depth for feeding, traveling, and calling whales. Increases in time spent at deep depths are generally attributed to lunge-feeding at those depths. (a) Feeding and traveling profiles for nonvocal whales; means +1 SD. (b) and (c) Percent time at depth profiles for individual $A B$ and $D$ callers, respectively, illustrating increased time spent at shallow depths, where calling occurs. Horizontal bar in both graphs represents the depth over which calling was heard. Dates: $\mathrm{mo} / \mathrm{d} / \mathrm{yr}$

sex, location, and condition to females (Payne \& McVay 1971, Winn \& Winn 1978, Tyack 1981). Singing also has been attributed to male fin whales (Croll et al. 2002). Fin whales produce relatively simple songs con- sisting of patterns of short, low-frequency downsweeps (Watkins 1981, Thompson et al. 1992), similar to the simplicity in structure of blue whale songs.

We report blue whale song that occurs during the feeding season, temporally and geographically separate from presumed breeding grounds in lower latitudes. Blue whale song is also known to occur on presumed eastern tropical Pacific breeding grounds during the summer and fall feeding seasons (Stafford et al. 2001), the purpose of which has not yet been explained. However, the phenomenon of singing during the non-reproductive feeding season is not unique to blue whales. Although humpback song is heard primarily on low-latitude breeding grounds (Payne \& McVay 1971), it has also been heard along migration routes (Clapham \& Matilla 1990, Cato 1991, Norris et al. 1999) and on feeding grounds (Mattila et al. 1987, McSweeney et al. 1989, Clark \& Clapham 2004). Clapham (1996) hypothesized that feeding-ground singing by humpbacks may serve as low-cost advertisement to estrous females who did not conceive the previous winter or may promote pair-bonding for the upcoming breeding season. This is supported by high rates of male-female association in the summer. Blue whales in the Gulf of St. Lawrence in the North Atlantic and along the California coast have been observed in male-female pairs during the feeding season (Sears 2002, J. Calambokidis unpubl. data). On these feeding grounds the incidence of pairing increases as the breeding season approaches, with some pairs remaining stable for at least several weeks. This may indicate that mate selection in blue whales is not confined seasonally, as has been suggested for humpback whales (Clapham 1996).

However, singing for reproductive purposes during the feeding season potentially presents a conflict for whales motivated to obtain food. The blue whale diet is fairly specialized, consisting almost exclusively of 2 species of euphausiids off the California coast (Croll et al. 1998, Fiedler et al. 1998). These euphausiid species are characterized by a patch distribution (Croll et al. 1998), and feeding whales are 
Table 3. Balaenoptera musculus. Summary of behavioral correlates with each calling type. 'Other calls': additional calls heard from focal whale; numbers in parentheses: known-sex individuals producing that call type. Function assessment based on observations from the present study and their concordance with observations in other published reports of calling whale behavior. AM/FM: amplitude-/frequency-modulated

\begin{tabular}{|c|c|c|c|c|}
\hline & Song AB & Singular A/B & $\mathrm{D}$ & $\mathrm{AM} / \mathrm{FM}$ \\
\hline $\mathrm{n}$ & $6(4)$ & $5(2)$ & $4(3)$ & 1 \\
\hline Sex & male & male & male \& female & male \\
\hline Behavior & traveling & $\begin{array}{c}\text { feeding, } \\
\text { traveling, milling }\end{array}$ & feeding & feeding \\
\hline Group size & 1 & $2-3$ & $1+$ & 1 \\
\hline Other calls & no & no & $\mathrm{AM} / \mathrm{FM}$ & $\mathrm{D}$ \\
\hline $\begin{array}{l}\text { Possible } \\
\text { function }\end{array}$ & reproduction & reproduction & $\begin{array}{c}\text { social } \\
\text { (food associated) }\end{array}$ & social \\
\hline
\end{tabular}

often localized within these prey patches. Our observations suggest that feeding whales tend to dive deeper than vocalizing whales and are milling or relatively stationary at the surface. When compared with the traveling behavior of singing blue whales, these observations suggest that feeding and singing are not mutually compatible. Blue whales range widely during a single feeding season (Calambokidis et al. 1990, Mate et al. 1999), covering up to $124 \mathrm{~km} \mathrm{~d}^{-1}$ (Mate et al. 1999) while searching for large concentrations of euphausiids. If blue whales use their travel time between foraging areas not only to move, but also to sing, they may be effectively signaling to potential mates while searching for food with little extra energy expenditure. Increased production of B calls at night (Stafford et al. 2005, Wiggins et al. 2005) also supports this conclusion. The diel vertical migration of blue whale prey into the surface waters at night (Brinton 1967) makes foraging less efficient during this period (Croll et al. 1998), suggesting that whales coordinate their singing and feeding behaviors by singing when prey are less available. Pair bonds formed either during foraging or as the result of attraction by a traveling singer may be maintained during feeding by infrequent production of $\mathrm{AB}$ calls.

A theoretical model of blue whale sound production presented by Aroyan et al. (2000) predicted an undulating dive profile to produce loud, low-frequency, long-duration type B calls. We did not find the significant changes in depth during $B$ call production required to support this hypothesis (Fig. 7). Instead, we suggest that the whale may choose its calling depth to maximize signal output and minimize energy expenditure. Calling at shallow depth may increase the strength and directionality of the blue whale call through degeneration of the produced omni-directional pattern (Aroyan et al. 2000, Clark \& Ellison
2004), into a dipole radiation pattern, directing energy into a downwardpointing lobe (Urick 1983). For a call produced at $1 / 4$ of an acoustic wavelength from the surface, or at $\sim 23 \mathrm{~m}$ at $16 \mathrm{~Hz}$, the energy reflected from the surface adds to that initially produced by the whale, increasing signal strength by $6 \mathrm{~dB}$. The average depth of $B$ call production observed here ranged from 20 to $30 \mathrm{~m}$, very close to the optimal depth for increased signal strength due to surface reflection. Further, analysis of the stroking and gliding of blue whales during deep diving (Williams et al. 2000) suggests that this species is neutrally buoyant at approximately $30 \mathrm{~m}$. Calling dives to depths of neutral buoyancy would further decrease the cost of producing calls, as the whale is able to maintain depth during calling without actively swimming.

The behavioral context of singular A and B calls appears to be more complex than that of singing. Singular A and B calls are similar in frequency and duration to song A and B units (Table 2), but the intermittent timing clearly distinguishes them from song. Whales producing singular calls were engaged in a variety of behaviors. However, a unifying characteristic is that only males that were part of a pair or group (Table 1) (with other blue whales in the immediate vicinity) produced this call type, suggesting that the intended receivers may be those nearby.

Tests of signal characteristics revealed significant differences in the start and end frequencies of song and singular calls (Table 2). These differences may be related to the function of the calls; however, it is more likely that they are due to the timing of sampling. Annual temporal change in blue whale call frequencies occurs such that the mid-frequency of A and B calls has decreased each year since the mid-1960s (Hildebrand et al. 2001). The authors also found that within-season variability of A and B call frequencies varied little within and between individuals. They concluded that blue whales synchronize their A and B call frequencies annually and, as a population, shift their call frequency at a predictable rate from one year to the next. Five of 6 of our observations occurred during or prior to 2002, the first year we observed singular calls. We would therefore expect differences in call frequency among song and singular calls related to the years in which they were collected. Within-year comparison of a larger sample of song and singular calls is needed to resolve whether our observations are characteristic of song versus singular calls or are due to an annual frequency shift. 


\section{Downswept D and highly variable calls}

D calls also appear to have an identifiable behavioral context. We observed D calls from blue whales of both sexes during breaks from foraging at depth. These whales were often paired with or close to other whales. Previous recordings of D calls have shown this call type to be quite variable and produced by both lone and aggregated whales (Thode et al. 2000, McDonald et al. 2001). McDonald et al. (2001) observed D calls from several whales in an alternating pattern and hypothesized that they were contact calls. Thode et al. (2000) observed multiple calls per dive, with calls produced throughout the dive profile at depths between 15 and $35 \mathrm{~m}$, similar to our observations. At these shallow depths, sufficient light should be available for visual identification of conspecifics.

The observations of Thode et al. (2000) and McDonald et al. (2001) as well as ours suggest that the function of D calls is likely to be related to social interaction, rather than reproduction. Our observations indicate that these calls are made by both sexes on feeding grounds, often in sets, and sometimes among nearby whales. Social sounds, as described by EddsWalton (1997), generally include repetitive frequency sweeps and are produced by 2 or more individuals in close proximity whose activity appears to be coordinated. Our observations of whales producing D calls are consistent with this description. Similar vocalizations have been recorded from several rorqual species. For example, fin whales have been observed producing $20 \mathrm{~Hz}$ pulse calls while traveling at distances of up to $3 \mathrm{~km}$ from each other (McDonald et al. 1995), perhaps as a means to maintain contact between individuals in the group. Contact vocalizations, produced by a single whale physically separated from a conspecific, result in interaction between the caller and the conspecific (Edds-Walton 1997). The fluidity of pairing observed during 2 recordings of D calls (28 July 2004 and 29 September 2003: Fig. 6) may be evidence of interaction between the caller and the conspecific resulting from $\mathrm{D}$ call production.

The presence of non-stereotyped tonal and amplitude-modulated calls indicates that blue whale calling behavior is more complex than previously recognized. Thode et al. (2000) also noted other 'highly modulated' variants occurring with $\mathrm{D}$ calls. The occasional association of these non-stereotyped calls with D calls suggests that their combined function may be different from that of D calls occurring alone. Increased signal complexity and variability have been shown to correlate with activity level in southern right whales (Clark 1983) and bowhead whales Balaena mysticetus (Wursig et al. 1985), and with agonistic interactions among fin whales (Watkins 1981, Edds 1988). The greater complexity of the AM and FM calls may be indicative of similar behavior in blue whales.

Our observations indicate that calls are produced at shallow depths, resulting in the temporal separation of feeding and calling activities. We have shown that calling whales spend significantly more time at shallow depths than foraging whales, indicating that call production may occur at the expense of foraging. For example, D callers and some singular AB callers break from feeding to call. Calling to attract conspecifics to the region may increase the ability of an individual to capture more prey, perhaps through cooperative herding; however, this possibility appears unlikely, as Crittercam video of foraging whales does not indicate cooperative feeding underwater (J. Calambokidis unpubl. data). However, there appears to be a premium on maintaining acoustic contact, although whether it functions to maintain pair bonds, attract mates, or deter conspecifics is not clear.

\section{Using tags to study vocal behavior}

Acoustic recording tags provide the ability to monitor the sounds produced by a whale within the context of diving behavior. When these observations are paired with surface behavioral observations and skin samples, a suite of variables are available for deducing the context of call production. When the context of calling is known, monitoring the occurrence of calls may provide a powerful means of delineating stocks, migration routes, and critical habitat (Mellinger \& Barlow 2003), assessing anthropogenic impact, and understanding the mating system and social structure of the population.

There are biases and limitations associated with observing calling behavior with tags. The computation of call source levels from tag recordings is not straightforward. The precise location of the acoustic source within the body must be known before transmission loss can be estimated. Depending on the location and dimension of the source, the tag may be within the acoustically complex near-field, preventing estimation of transmission loss without acoustic velocity measurements. Further, the acoustic path of the sound through the whale may be complicated by interference with bones and air-filled structures, further complicating the estimation of transmission loss. Before call source levels may be reliably estimated from tag recordings they must be verified against source levels computed from simultaneous recordings collected at a greater distance, where the precise internal location of the source is negligible, and where the transmission properties of the water column are known. 
It is often difficult to place a tag on a quickly moving whale or one with erratic surfacing patterns. If these whales have different diving and vocal behaviors from other whales then our results will not represent this subset of the population. We have attempted to reduce this bias by increasing the duration of tag attachment with the expectation that any whale that can be tagged may eventually exhibit other behaviors while the tag is attached. We have found some success in achieving longer recording duration through experimentation with suction cup material, number, and size. In addition to recording a greater variety of dive behaviors, longer attachments may increase the probability of detecting calls.

\section{Future studies}

Our tag deployments and focal whale observations occurred almost exclusively within the feeding season off California. Future observations in different regions and during different seasons may sample behaviors quite different from those we have reported here. However, our findings do yield some hypotheses upon which future studies may be based.

First, we suggest that the number of singularly calling whales may be equal to or greater than the number of singing whales in some regions and seasons. We have sampled equal numbers of singularly calling and song calling whales (Table 1). The similarity in frequency and duration of singular A and B calls to song $A B$ calls has probably prevented their unique identification previously; however, it appears that the singular $A B$ call type is prevalent on feeding grounds. The number of singular callers and their calling rate will impact efforts to estimate abundance based on the occurrence of A and B calls. More observations of singularly calling blue whales are needed before their relation to foraging versus reproductive behaviors may be understood.

Second, monitoring the presence of D and singular A and/or B call types may provide a more direct means for delineating whale habitat, as these calls have been heard from feeding whales in known foraging areas. The detection of these call types, together with environmental data (e.g. sea-surface temperature, surface chlorophyll, sea-surface height) may allow the development of predictive models of habitat. Long-term acoustic monitoring of individual blue whales paired with measures of body condition and proximity to food resources could provide insight into the precise functions of these call types.

Finally, we suggest that calling is not energetically expensive. The data we present here provide preliminary support of this hypothesis in that the diving behavior of calling whales does not differ significantly from non-calling whales. More support may be found in detailed studies of blue whale movement during calling and non-calling periods. These studies should include independent measurement of acoustic source levels to evaluate if and how blue whales change their call output in response to local environmental conditions or nearby whale behavior.

Acknowledgements. Tracking and tagging blue whales requires the support of many institutions and people. Funding for this work was provided by the Navy's Strategic Environmental Research and Development Program (SERDP), the Chief of Naval Operations (CNO-N45), the Office of Naval Research (ONR), the Tagging of Pacific Pelagics Program (TOPP), and the Center for Integrated Marine Technology (CIMT) at the University of California, Santa Cruz. Tagging and biopsy activities were permitted under US National Marine Fisheries Service Scientific Research Permit No. 5401502-00. T. Chandler and J. Harvey provided expert boat handling and tagging assistance. Visual and acoustic observers from Cascadia Research Collective, Moss Landing Marine Laboratories, and SIO, and D. Croll and K. Newton of UCSC aided in finding and tracking singing and tagged blue whales. J. Olson of Cetacean Research Technology designed and manufactured the tag flotation and attachment system. J. Francis, G. Marshall, and M. Bahktiari of National Geographic provided the Crittercam; and R. Woodward, M. Johnson, and P. Tyack of Woods Hole Oceanographic Institution provided the D-tag. Analysis of blue whale tissue samples was possible through the cooperation of B. Taylor, S. Chivers, and K. Robertson at NOAA-Southwest Fisheries Science Center. D. Gendron of CICMAR provided critical support allowing for blue whale tagging in Mexico. The captains and crews of the RV 'Robert Gordon Sproul' and RV 'John Martin' deserve special thanks for their tireless work at sea during our tagging and tracking operations. The work presented in this manuscript was part of the doctoral dissertation of E.M.O. under the watchful eye of her doctoral committee: J.A.H, J. Barlow, P. Dayton, S. Moore, D. Checkley, and J. Moore. Previous versions of this manuscript were significantly improved by the tremendous contributions of S. Cerchio and 4 anonymous reviewers.

\section{LITERATURE CITED}

Acevedo-Gutierrez A, Croll DA, Tershy BR (2002) High feeding costs limit dive time in the largest whales. J Exp Biol 205:1747-1753

Aroyan JL, McDonald MA, Webb SC, Hildebrand JA, Clark DS, Laitman JT, Reidenberg JS (2000) Acoustic models of sound production and propagation. In: Au WWL, Popper AN, Fay RN (eds) Hearing by whales and dolphins. Springer-Verlag, New York, p 409-469

Bradbury JW, Vehrencamp SL (1998) Principle of animal communication. Sinauer Associates, Sunderland, MA

Brinton E (1967) Vertical migration and avoidance capability of eupahusiids in the California Current. Limnol Oceanogr 12:451-483

Burtenshaw JC, Oleson EM, McDonald MA, Hildebrand JA, Andrew RK, Howe BM, Mercer JA (2004) Acoustic and satellite remote sensing of blue whale seasonality and habitat in the Northeast Pacific. Deep-Sea Res II 51:967-986 
Calambokidis J, Steiger GH, Cubbage JC, Balcomb $\mathrm{KC}$, Ewald E, Kruse S, Wells R, Sears R (1990) Sightings and movements of blue whales off central California 1986-88 from photo-identification of individuals. Rep Int Whal Commn Spec Issue 12:343-348

Cato DH (1991) Songs of humpback whales: the Australian perspective. Mem Queensl Mus 30:227-290

Clapham PJ (1996) The social and reproductive biology of humpback whales: an ecological perspective. Mammal Rev 26:27-49

Clapham PJ, Matilla DK (1990) Humpback whale songs as indicators of migration routes. Mar Mamm Sci 6:155-160

Clark CW (1983) Acoustic communication and behavior of the southern right whale (Eubalaena australis). In: Payne R (ed) Communication and behavior of whales. Westview Press, Boulder, CO, p 163-198

Clark CW, Clapham PJ (2004) Acoustic monitoring on a humpback whale (Megaptera novaeangliae) feeding ground shows continual singing into late spring. Proc R Soc Lond Ser B 271:1051-1057

Clark CW, Ellison WT (2004) Potential use of low-frequency sounds by baleen whales for probing the environment: evidence from models and empirical measurements. In: Thomas JA, Moss CF, Vater M (eds) Echolocation in bats and dolphins. University of Chicago Press, Chicago, IL, p 604

Croll DA, Tershy BR, Hewitt RP, Demer DA and 8 others (1998) An integrated approach to the foraging ecology of marine birds and mammals. Deep-Sea Res 45:1353-1371

Croll DA, Clark CW, Acevedo A, Tershy BR, Flores RS, Gedamke J, Urban RJ (2002) Only male fin whales sing loud songs. Nature 417:809

Darling JD (1983) Migrations, abundance, and behavior of Hawaiian humpback whales, Megaptera novaeangliae (Borowski). PhD thesis, University of California, Santa Cruz

Darling JD, Berube M (2001) Interactions of singing humpback whales with other males. Mar Mamm Sci 17:570-584

D'Vincent CG, Nilson RM, Hanna RE (1985) Vocalizations and coordinating feeding behavior of the humpback whales in southeast Alaska. Sci Rep Whales Res Inst Tokyo 36:41-47

Edds PL (1988) Characteristics of finback Balaenoptera physalus vocalizations in the St. Lawrence Estuary. Bioacoustics 1:131-149

Edds-Walton PL (1997) Acoustic communication signals of mysticete whales. Bioacoustics 8:47-60

Evans WE (1967) Vocalizations among marine mammals. In: Tavolga WN (ed) Marine bio-acoustics, Vol 2. Pergamon Press, New York, p 159-186

Fiedler PC, Reilly SB, Hewitt RP, Demer DA and 6 others (1998) Blue whale habitat and prey in the California Channel Islands. Deep-Sea Res II 45:1781-1801

Goldbogen JA, Calambokidis J, Shadwick RE, Oleson EM, McDonald MA, Hildebrand JA (2006) Kinematics of foraging dives and lunge-feeding in fin whales. J Exp Biol 209: 1231-1244

Hildebrand JA, McDonald MA, Andrew RK, Mercer JA, Howe BM (2001) Multiyear study of blue whale calls in the North Pacific. J Acoust Soc Am 110:2271

Johnson MP, Tyack P (2003) A digital acoustic recording tag for measuring the response of wild marine mammals to sound. IEEE (Inst Electr Electron Eng) Ocean Eng 28:3-12

Kroodsma DE, Miller EH (1982) Acoustic communication in birds. Academic Press, New York

Marshall GJ (1998) CRITTERCAM: an animal borne imaging and data logging system. Mar Technol Soc J 32:11-17
Mate BR, Lagerquist BA, Calambokidis J (1999) Movements of North Pacific blue whales during the feeding season off southern California and their southern fall migration. Mar Mamm Sci 15:1246-1257

Mattila DK, Guinee LN, Mayo CA (1987) Humpback whales songs on a North Atlantic feeding ground. J Mammal 68: 880-883

McDonald MA (2004) DIFAR hydrophones applied to whale research. Can J Acoust 32:155-160

McDonald MA, Hildebrand JA, Webb SC (1995) Blue and fin whales observed on a seafloor array in the Northeast Pacific. J Acoust Soc Am 95:712-721

McDonald MA, Calambokidis J, Teranishi AM, Hildebrand JA (2001) The acoustic calls of blue whales off California with gender data. J Acoust Soc Am 109:1728-1735

McDonald MA, Mesnick SL, Hildebrand JA (2006) Biogeographic characterization of blue whale song worldwide: using song to identify populations. J Cetacean Res Manage 8:55-65

McSweeney DJ, Chu KC, Dolphin WF, Guinee LN (1989) North Pacific humpback whale songs - a comparison of southeast Alaska feeding ground songs with Hawaiian wintering ground songs. Mar Mamm Sci 5:139-148

Mellinger DK (2002) ISHMAEL: integrated system for holistic multi-channel acoustic exploration and localization. Pacific Marine Environmental Laboratory, Newport, OR

Mellinger DK, Barlow J (2003) Future directions for acoustic marine mammal surveys: stock assessment and habitat use. Report of a workshop held in La Jolla, CA, 20-22 November 2002. NOAA GAR Special Report, Seattle, WA

Mellinger DK, Clark CW (2003) Blue whale (Balaenoptera musculus) sounds from the North Atlantic. J Acoust Soc Am 114:1108-1119

Morin PA, Nestler A, Rubio-Cisneros NT, Robertson KM, Mesnick SL (2005) Interfamilial characterization of a region of the ZFX and ZFY genes facilitates sex determination in cetaceans and other mammals. Mol Ecol 14:3275-3286

Norris TF, McDonald MA, Barlow J (1999) Acoustic detections of singing humpback whales (Megaptera novaeangliae) in the eastern North Pacific during their northbound migration. J Acoust Soc Am 106:506-514

Parks SE, Tyack PL (2005) Sound production by North Atlantic right whales (Eubalaena glacialis) in surface active groups. J Acoust Soc Am 117:3297-3306

Patterson B, Hamilton GR (1964) Repetitive 20 cycle per second biological hydroacoustic signals at Bermuda. In: Tavolga WN (ed) Marine bio-acoustics, Vol 1. Pergamon Press, New York, p 125-146

Payne R, McVay S (1971) Songs of humpback whales. Science 173:585-597

Payne R, Webb D (1971) Orientation by means of long range acoustical signaling in baleen whales. Ann NY Acad Sci 188:110-141

Rankin S, Ljungblad DK, Clark CW, Kato H (2005) Vocalisations of Antarctic blue whales, Balaenoptera musculus intermedia, recorded during the 2001/2002 and 2002/2003 IWC/SOWER circumpolar cruises, Area V, Antarctica. J Cetacean Res Manage 7:13-20

Sears R (2002) Blue whale. In: Perrin WF, Wursig B, Thewissen JGM (eds) Encyclopedia of marine mammals. Academic Press, San Diego, CA, p 112-116

Stafford KM (2003) Two types of blue whale calls recorded in the Gulf of Alaska. Mar Mamm Sci 19:682-693

Stafford KM, Nieukirk SL, Fox CG (2001) Geographic and seasonal variation of blue whale calls in the North Pacific. J Cetacean Res Manage 3:65-76 
Stafford KM, Moore SE, Fox CG (2005) Diel variation in blue whale calls recorded in the eastern tropical Pacific. Anim Behav 69:951-958

Thode AM, D'Spain GL, Kuperman WA (2000) Matched-field processing, geoacoustic inversion, and source signature recovery of blue whale vocalizations. J Acoust Soc Am 107:1286-1300

Thompson PO (1965) Marine biological sounds west of San Clemente Island: diurnal distributions and effects of ambient noise during July 1963. Rep 1290. US Navy Electronics Laboratory, San Diego, CA

Thompson PO, Findley LT, Vidal O (1992) 20-Hz pulses and other vocalizations of fin whales, Balaenoptera physalus, in the Gulf of California, Mexico. J Acoust Soc Am 92: 3051-3057

Thompson PO, Findley LT, Vidal O, Cummings WC (1996) Underwater sounds of blue whales, Balaenoptera musculus, in the Gulf of California, Mexico. Mar Mamm Sci 13:288-293

Tyack P (1981) Interactions between singing humpback whales and conspecifics nearby. Behav Ecol Sociobiol 8:

Editorial responsibility: Rory Wilson (Contributing Editor), Swansea, UK
$105-116$

Urick RJ (1983) Principles of underwater sound. Peninsula Publishing, Los Altos, CA

Watkins WA (1981) Activities and underwater sounds of fin whales. Sci Rep Whales Res Inst Tokyo 33:83-117

Williams TM, Davis RW, Fuiman LA, Francis J, LeBoeuf BJ, Horning M, Calambokidis J, Croll DA (2000) Sink or swim: strategies for cost-efficient diving by marine mammals. Science 288:133-136

Wiggins SM, Oleson EM, McDonald MA, Hildebrand JA (2005) Blue whale (Balaenoptera musculus) diel calling patterns offshore southern California. Aquat Mamm 31: 161-168

Winn HE, Winn LK (1978) The song of the humpback whale Megaptera novaeangliae in the West Indies. Mar Biol 47: 97-114

Wursig B, Dorsey EM, Fraker MA, Payne RS, Richardson WJ (1985) Behavior of bowhead whales, Balaena mysticetus, summering in the Beaufort Sea: a description. Fish Bull 83: 357-377

Submitted: January 11, 2006; Accepted: May 11, 2006 Proofs received from author(s): January 9, 2007 